\title{
STUDENTS' PERCEPTION ON DIGITAL LEARNING DURING LOCKDOWN PERIOD IN INDIA: AN EMPIRICAL STUDY OF RURAL AND URBAN COMMUNITY
}

\author{
Miklesh Prasad Yadav \\ Assistant Professor, ACCF, Amity University Noida \\ Madhu Arora \\ Associate Professor, RDIAS, Delhi-110085 \\ Sunil Kumari \\ Assistant Professor, Govt. College Meham, Rohtak, India \\ Sanjay Nandal \\ Assistant Professor, IMSAR, MDU Rohtak, India
}

\begin{abstract}
The digital journey of learning has been of different perception to different community. We study the perception of students regarding online learning during lockdown period in three different communities of India i.e. rural, urban and metropolitan on the basis of survey of 411 students during lockdown period. Ten problem statements have been considered to be rated at Likert's Five Scale. To check the reliability, Cronbach's a, to analyze the data- mean \& standard deviation and to validate the results t-test and Post Hoc Test have been used. It is concluded that majority of students have smart phones in urban and metropolitan but neutral to learning while rural students prefer the conventional leaning. This study contributes to the new theory of the efficacy of digital learning as mode of learning in and after lock down period that will bring the attention of educational agencies, faculty members as well as policy makers towards the problems faced by the students in digital learning.
\end{abstract}

Key words: Digital, Learning, Online, Teaching, Students, Lockdown.

\section{INTRODUCTION}

Education is inevitable thing which changes the world into something better. Everyone in this globe wants a good education to develop in them a perspective of looking at life. There are innumerable ways to get education and bring it in the learning process like physical presence (attending class in School/College/Institute) and online learning (remote). Majority of the students prefer physical presence in the classroom but this COVID-19 outbreak has now entrapped the whole world and compelled students to go through online mode of learning. But due to the less availability online facilities, students have not been able to grasp knowledge properly.

The online journey of learning has been of different perception to different community. The students of rural community have different opinion whereas the students of urban community have different perception.
As per world meter around 200 countries have got influenced by it. Corona havoc is rising day by day very speedily; consequently most of the affected countries even the territories therein, have announced the locked down. Economies are getting stagnant being stopped the all kinds of activities and movements. No doubt, digital media is emerging in a vital role in different modes in handling such lock down period of facing pandemic COVID-19 (Sachdeva, P., \& Tripathi, D, 2019; Kabha, R., Kamel, A., Elbahi, M., \& Narula, S., 2019 \& Singh, P., 2019). Target vectors and educational technology are being affected by digital transformation of the economies in present scenario (Zakharova Nadezhda, Polyakov Kirill et.al.2019). Different states have started to ride on digital media to provide the online services. Every nation is trying to protect its primary and core field i.e. education from the effects of locked down. Hence, it has become the necessity of time to address the educational work stoppage due to corona crisis (Hindustan Times, 2020). 
However, majority of the nations haven't adopted a country wide school or college closure policies, it rests with local authorities. In context of India, the State Governments have declared the closure on extension basis (UNESCO, 2020).

During this critical condition, digital learning is evolving as a solution to the problem. Digital learning may be in various forms like Mobile Assisted Learning (MAL), Computer Assisted Learning (CAL), Technology Enhanced Learning (TEL), Computer Mediated Communication (CMC) etc. To pursue the distance teaching-learning process in digital form, India has announced a list of digital channels which could enable the students, teachers as well as researchers, an online learning platform in lock down, which includes SWAYAM, MOOCS, E-Pathshala, CEC-UGC U-tube Channels, Shodh Ganga, Vidwan, E-Shodh Sindhu etc. (MINISTRY OF EDUCATION, Govt. of India, 2020). Various apps are also being offered to be installed to access, upload or retrieve the e-content, of which "Zoom" is getting very popular to conduct the online classes via cloud technology. Further social networking systems like whatsapp, facebook, twitters, skype, Utube etc. are also playing an eminent role in setting up the interactions between teachers and students. Virtual labs, digital library inflibnet, Google classrooms, Google forms and spoken tutorials etc. are also being recognized as effective means of knowledge transmission in digital mode. But how effectively these means are in tackling the present situation is researchable.

India, like many developing countries across the globe, is badly equipped to deal with what's to come. Having understood the insufficiency of digital faculty and in light of the many challenges being reported by parents and students across the country, the Ministry of Human Resources and Development launched a "Bharat Padhe Online" campaign on April 12, 2020 for crowd sourcing of ideas to improve the online education flora and fauna of India. However, it remains unclear as to which ideas will see light of day as the urbanrural education gap further widens amidst the looming COVID-19 crisis. This paper attempts to answer the question "Is there any significant difference in the perception of students residing in rural, urban and metropolitan area regarding online learning during lockdown period?"

The paper is categorized into five different sections including the present one. Section 2 discusses review of literature, section 3 presents research methodology, results and discussion and conclusion are provided in section 4 and section 5 respectively.

\section{LITERATURE REVIEW}

Rainie \& Horrigan (2005) quoted that in all income groups whether it is low income or high, computers and internet access at high speed seem now everywhere in US ménages. Petri Nokelainen (2006) presented the pedagogical usability criteria and stated that theoretical aspect of how to design the digital learning content should also be considered equally important as technical one. To test the results of study, two samples- one of 66 students of $5^{\text {th }}$ standard and second one of 74 students of $6^{\text {th }}$ standards of elementary education, were taken under which students were given to evaluate one LMS and four LMs with PMLQ. Study found that the PMLQ was capable to apprehend the differences in the instructional usability profiles of the learning modules. Warschauer (2007) stated that curricular and pedagogic methodologies to educational technology, occur which can stand-in to improve the digital learning for all. Hidaayatullaah et.al. (2020) found the entire global educational arena including Indonesia, significantly influenced by COVID-19. Conventional learning has been shifted to digital mode of learning. Digital learning is not new one but it had gained the importance before this corona crisis to keep the pace with industrialization 4.0 and community 5.0. Mahalakshmi and Radha (2020) stated in their study that COVID-19 has accelerated the pace of "Digital India", an initiative of Govt. of India launched recently. The lockdown has collapsed the traditional teaching and learning system. However corona is worsening the entire globe but in spite of that it's a positive thing that it has promoted digital learning marvelously.

Crawford, Joseph, Butler-Henderson, et al. (2020) collected higher education responses on COVID 19, particularly of universities of 20 countries across the globe. On the basis of 172 secondary sources of information and found that all developed countries except US are 
running online classes and have not declared the semester break. Majority of the developing nations are not in the position to run online classes due to lack of IT infrastructure, remote reach, skillsets, content availability etc. Moreover, the focus of organizations being closed, is shifting to online pedagogy. Revees et.al. (2020) stated that to assist the students in learning, business players can provide the online educational services partnered with the ministry of education through opening of the nationwide digital cloud classrooms.

Further, Eisenstein in 1979, Ong in 1982, Harvard Discussions in 1991, Winston and Attewell in 200, Chengyi Lin in Harvard Business Review 2020 and so many other studies or scholars have quoted the importance of digital learning and literacy earlier, whereas in present scenario, digital learning is gaining much more importance and seems the necessity of the hour. No previous study has focused on problems faced by the students on account of sudden adoption of digital learning. Hence the present study fills the research gap existing in the field of education with reference to present critical period of lock down. Referring the above detailed review of literature and research gap, following hypotheses are formulated:

H0: There is no significant difference in perception of students about online digital learning in Rural and Urban Area during lock down period.

H1: There is significant difference in perception of students about online digital learning in rural and urban area during lockdown period.

\section{Research Methodology}

Present study is descriptive in nature. Responses of a sample of 411 students selected from two states (Delhi, Haryana) through snow ball sampling technique were recorded by imparting structured questionnaire. got filled up in Google Form from focus group i.e. 411 students residing in two states -Haryana and Delhi during the lockdown period, selected on the basis of snow ball sampling. Ten problem statements have been taken to be rated at Likert's Five Scale. Reliability of data has been checked terms of Cronbach's a. Mean, Standard deviation, T-test and Post Hoc Test have been used to analyze the data.
Jamovi software has been used for statistical computation and validation of results.

\section{Results \& Discussions}

Reliability Analysis: This analysis checks the internal consistency of responses or data collected. The rule given by George and Mallery (2003) has been followed to interpret internal consistency output.

Table 1.1 Scale Reliability Statistics

\begin{tabular}{|l|l|l|l|}
\hline & Mean & SD & Cronbach's a \\
\hline Scale & 2.91 & .901 & .837 \\
\hline
\end{tabular}

Source: Authors' Calculations

Value of Cronbach's alpha is 0.837 with mean 2.91 and standard deviation 2.91 which shows statements have internal consistency as value of 0.70 or higher is considered good.

Table 1.2 Item Reliability Statistics

\begin{tabular}{|l|l|}
\hline & $\begin{array}{l}\text { if item } \\
\text { dropped } \\
\text { Cronbach's a }\end{array}$ \\
\hline Statement & 0.824 \\
\hline $\begin{array}{l}\text { I face problem in digital learning } \\
\text { in lock down period as it is not } \\
\text { user friendly }\end{array}$ & 0.825 \\
\hline $\begin{array}{l}\text { I face problem in digital learning } \\
\text { in lock down period as difficult } \\
\text { to learn than conventional } \\
\text { offline learning }\end{array}$ & 0.822 \\
\hline $\begin{array}{l}\text { I face problem in digital learning } \\
\text { in lock down period as it is } \\
\text { difficult to understand }\end{array}$ & 0.825 \\
\hline $\begin{array}{l}\text { I do not have } \\
\text { smartphone/laptop or device } \\
\text { for digital learning }\end{array}$ & 0.819 \\
\hline I do not have access to internet & 0.814 \\
\hline $\begin{array}{l}\text { I can't afford data package for } \\
\text { digital learning }\end{array}$ & 0.826 \\
\hline $\begin{array}{l}\text { lack of Electricity/regular power } \\
\text { supply is problem in digital } \\
\text { learning }\end{array}$ & 0.822 \\
\hline $\begin{array}{l}\text { I feel problems in digital } \\
\text { learning as I do not have smart } \\
\text { phone }\end{array}$ & 0.822 \\
\hline $\begin{array}{l}\text { I feel problems in digital } \\
\text { learning as it takes more time } \\
\text { than traditional lecture }\end{array}$ & 0.824 \\
\hline $\begin{array}{l}\text { I feel problems in digital } \\
\text { learning as I do not have } \\
\text { knowledge how to use }\end{array}$ & \\
\hline Source A A & \\
\hline
\end{tabular}

Source: Authors' Calculations 
Table 1.2 demonstrates the impact on internal consistency on statements if one item is dropped. It is obvious that all values are more than 0.70 , so no single statement have extreme impact, all statements are normal.
Opinion of Students of Rural Area $(\mathrm{N}=208)$ states that they feel very few problems in digital learning due to not having smart phone (Mean=2.09, Standard Deviation=1.399, Standard Error=0.0970). Also students of

Table 2.1 Group Descriptive about Perception of Students in Digital Learning during Lock down Period

\begin{tabular}{|c|c|c|c|c|c|}
\hline & Residence & $\mathbf{N}$ & Mean & SD & SE \\
\hline \multirow{3}{*}{$\begin{array}{l}\text { I face problem in digital learning in lock down } \\
\text { period as it is not user friendly }\end{array}$} & Rural & 208 & 3.40 & 1.551 & 0.1075 \\
\hline & Urban & 138 & 3.52 & 1.314 & 0.1118 \\
\hline & Metropolitan & 65 & 3.37 & 1.219 & 0.1512 \\
\hline \multirow{3}{*}{$\begin{array}{l}\text { I face problem in digital learning in lock down } \\
\text { period as difficult to learn than conventional } \\
\text { offline learning }\end{array}$} & Rural & 208 & 3.88 & 1.362 & 0.0944 \\
\hline & Urban & 138 & 3.76 & 1.241 & 0.1057 \\
\hline & Metropolitan & 65 & 3.86 & 1.236 & 0.1533 \\
\hline \multirow{3}{*}{$\begin{array}{l}\text { I face problem in digital learning in lock down } \\
\text { period as it is difficult to understand }\end{array}$} & Rural & 208 & 3.92 & 1.363 & 0.0945 \\
\hline & Urban & 138 & 3.56 & 1.351 & 0.1150 \\
\hline & Metropolitan & 65 & 3.46 & 1.324 & 0.1642 \\
\hline \multirow{3}{*}{$\begin{array}{l}\text { I do not have smartphone/laptop or device for } \\
\text { digital learning }\end{array}$} & Rural & 208 & 2.28 & 1.478 & 0.1025 \\
\hline & Urban & 138 & 1.87 & 1.317 & 0.1121 \\
\hline & Metropolitan & 65 & 1.54 & 0.969 & 0.1202 \\
\hline \multirow[t]{3}{*}{ I do not have access to internet } & Rural & 208 & 2.51 & 1.516 & 0.1051 \\
\hline & Urban & 138 & 2.09 & 1.293 & 0.1100 \\
\hline & Metropolitan & 65 & 1.86 & 1.210 & 0.1501 \\
\hline \multirow[t]{3}{*}{ I can't afford data package for digital learning } & Rural & 208 & 3.10 & 1.601 & 0.1110 \\
\hline & Urban & 138 & 3.06 & 1.584 & 0.1348 \\
\hline & Metropolitan & 65 & 2.12 & 1.386 & 0.1720 \\
\hline \multirow{3}{*}{$\begin{array}{l}\text { lack of Electricity/regular power supply is } \\
\text { problem in digital learning }\end{array}$} & Rural & 208 & 2.88 & 1.589 & 0.1102 \\
\hline & Urban & 138 & 2.57 & 1.499 & 0.1276 \\
\hline & Metropolitan & 65 & 2.29 & 1.331 & 0.1651 \\
\hline \multirow{3}{*}{$\begin{array}{l}\text { I feel problems in digital learning as I do not } \\
\text { have smart phone }\end{array}$} & Rural & 208 & 2.09 & 1.399 & 0.0970 \\
\hline & Urban & 138 & 1.68 & 1.101 & 0.0937 \\
\hline & Metropo & 65 & 1.62 & 0.963 & 0.1195 \\
\hline \multirow{3}{*}{$\begin{array}{l}\text { I feel problems in digital learning as it takes } \\
\text { more time to understand than traditional lecture }\end{array}$} & Rural & 208 & 3.71 & 1.426 & 0.0988 \\
\hline & Urban & 138 & 3.57 & 1.323 & 0.1126 \\
\hline & Metropolitan & 65 & 3.22 & 1.420 & 0.1761 \\
\hline \multirow{3}{*}{$\begin{array}{l}\text { I feel problems in digital learning as I do not } \\
\text { have knowledge how to use }\end{array}$} & Rural & 208 & 3.07 & 1.416 & 0.0982 \\
\hline & Urban & 138 & 2.57 & 1.361 & 0.1159 \\
\hline & Metropolitan & 65 & 1.85 & 1.228 & 0.1523 \\
\hline
\end{tabular}

\section{Source: Authors' Calculations}

Observation states that Students of Rural Area $(\mathrm{N}=208)$ feel very few problems in digital learning in lock down period as it is not user friendly (Mean=3.40, Standard Deviation=1.551, Standard Error=0.1075). Also students of Urban Area have less problems of having smart phone $(\mathrm{N}=138)$, (Mean=3.52, Standard Deviation=1.1314, Standard Error $=0.1118$ ) and students of Metropolitan Area ( $N=65$ ) feel very less problems in digital learning in lock down period as it is not user friendly (Mean=3.37, Standard Deviation=1.219, Standard Error=0.1512).
Urban Area have less problems of having smart phone $(\mathrm{N}=138)$, (Mean=1.68, Standard Deviation=1.101, Standard Error=0.0937) and students of Metropolitan Area $(\mathrm{N}=65)$ feel very less problems in digital learning due to? (Mean=1.62, Standard Deviation=0.963, Standard Error=0.1195). As in three cases mean is less than 3 , it is observed that lack of smart phone is not an issue in any location now. Also Students of Rural Area $(\mathrm{N}=208)$ feel more problems in digital learning as takes more time to understand than traditional lecture $($ Mean=3.71, Standard Deviation=1.426, 
Standard Error=0.0988) than students of Urban Area $(\mathrm{N}=138)$, (Mean=3.57, Standard Deviation=1.323, Standard Error $=0.1126$ ) and students of Metropolitan Area $(\mathrm{N}=65)$ feel less problems in digital learning (Mean=3.22, Standard Deviation=1.420, Standard Error=0.1761). the perception of students in rural, urban and metropolitan location about problem in digital learning in lock down period as difficult to learn as conventional offline learning $(\mathrm{F}=.372$, $\mathrm{p}$ value $=.690)$ at 5 percent level of significance. Hence Null hypothesis $(\mathrm{H} 0)$ is accepted. Also there is a significant difference in the perception of students in rural, urban

Table 2.2 One-Way ANOVA (Welch's) and empirical results about perception of students in digital learning during lock down period

\begin{tabular}{|c|c|c|c|c|}
\hline Statements & $\mathbf{F}$ & $\begin{array}{l}\mathbf{P} \\
\text { value }\end{array}$ & $\begin{array}{l}\text { Decision } \\
\text { Rule }\end{array}$ & $\begin{array}{l}\text { Significant } \\
\text { association }\end{array}$ \\
\hline $\begin{array}{l}\text { I face problem in digital learning in lock down period } \\
\text { as it is not user friendly }\end{array}$ & 0.448 & 0.640 & $\begin{array}{l}\text { H0 } \\
\text { Accepted }\end{array}$ & No \\
\hline $\begin{array}{l}\text { I face problem in digital learning in lock down period } \\
\text { as difficult to learn than conventional offline learning }\end{array}$ & 0.372 & 0.690 & $\begin{array}{l}\text { H0 } \\
\text { Accepted }\end{array}$ & No \\
\hline $\begin{array}{l}\text { I face problem in digital learning in lock down period } \\
\text { as it is difficult to understand }\end{array}$ & 4.520 & 0.012 & $\begin{array}{l}\text { H0 } \\
\text { Rejected }\end{array}$ & Yes \\
\hline $\begin{array}{l}\text { I do not have smartphone/laptop or device for digital } \\
\text { learning }\end{array}$ & 11.356 & $<.001$ & $\begin{array}{l}\text { H0 } \\
\text { Rejected }\end{array}$ & Yes \\
\hline I do not have access to internet & 7.475 & $<.001$ & $\begin{array}{l}\text { H0 } \\
\text { Rejected }\end{array}$ & Yes \\
\hline I can't afford data package for digital learning & 12.480 & $<.001$ & $\begin{array}{l}\text { H0 } \\
\text { Rejected }\end{array}$ & Yes \\
\hline $\begin{array}{l}\text { Lack of Electricity/regular power supply is problem } \\
\text { in digital learning }\end{array}$ & 4.634 & 0.011 & $\begin{array}{l}\text { H0 } \\
\text { Rejected }\end{array}$ & Yes \\
\hline $\begin{array}{l}\text { I feel problems in digital learning as I do not have } \\
\text { smart phone }\end{array}$ & 6.451 & 0.002 & $\begin{array}{l}\text { H0 } \\
\text { Rejected }\end{array}$ & Yes \\
\hline $\begin{array}{l}\text { I feel problems in digital learning as it takes more } \\
\text { time than traditional lecture }\end{array}$ & 3.025 & 0.051 & $\begin{array}{l}\text { H0 } \\
\text { Rejected }\end{array}$ & Yes \\
\hline $\begin{array}{l}\text { I feel problems in digital learning as I do not have } \\
\text { knowledge how to use? }\end{array}$ & 23.136 & $<.001$ & $\begin{array}{l}\text { H0 } \\
\text { Rejected }\end{array}$ & Yes \\
\hline
\end{tabular}

\section{Source: Authors' computations}

About feeling more problems in digital learning Students of Rural Area $(\mathrm{N}=208)$ opine that they do not have knowledge how to use (Mean=3.07, Standard Deviation=1.416, Standard Error=0.0982) than students of Urban Area $(\mathrm{N}=138)$, (Mean=2.57, Standard Deviation=1.361, Standard Error $=0.1159$ ) and students of Metropolitan Area ( $N=65)$ feel less problems in digital learning (Mean=1.85, Standard Deviation=1.228, Standard Error=0.1523).

As table 2.2 states that there is no significant association in the perception of students in rural, urban and metropolitan location about problem in digital learning in lock down period as it is not user friendly $(\mathrm{F}=.448, \mathrm{p}$ value $=.640)$ at 5 percent level of significance. Hence Null hypothesis (H0) is accepted. Similarly there is no significant association in and metropolitan location about problems in digital learning as they do not have do not have smart phone $(\mathrm{F}=6.451$, $\mathrm{p}$ value $<.002)$ at 5 percent level of significance. Hence Null hypothesis $(\mathrm{H} 0)$ is rejected. Also there is a significant difference in the perception of students in rural, urban and metropolitan location about problems in digital learning as they it takes more time to understand the concept than traditional lecture $(F=3.025, p$ value $=0.051)$ at 5 percent level of significance. Hence Null hypothesis (H0) is rejected. As a contrary there is a significant difference in the perception of students in rural, urban and metropolitan location about problems in digital learning as they do not have knowledge how to use $(\mathrm{F}=23.136$, $\mathrm{p}$ value< $.001)$ at 5 percent level of significance. Hence Null hypothesis (H0) is rejected. 
Tukey Post-Hoc Test is a test to check the significant difference if categories are more than two. Hence three categories are students of rural area, urban area and metropolitan area. This test will show the results of rural area with urban area as well as rural area with metro Politian area. Decision rule is just like as earlier that accept the null hypothesis if not found significant and reject the null hypothesis if found significant.

Table 3.1 indicates that there is significant difference in perception of students about ? it is difficult to understand in rural area with metropolitan area As Mean difference is .364 in urban and .4615 in metropolitan respectively. T- Value is 2.46 in urban area and rural with in metropolitan area is 2.40 . Hence value is more than 2 so significant difference is visible as $\mathrm{p}$ value is 0.038 with rural and Urban as well as $p=0.044$ in rural vs. metropolitan. Decision rule says null hypothesis is rejected. But looking at observation of Urban Vs. Metropolitan area there is no significant difference in perception of students about impact of online learning about it is difficult to understand as $p$ value is 0.884. Null hypothesis is accepted.

Table 3.2 indicates that there is significant difference in perception of students about smartphone/laptop or device for digital learning with metropolitan area As Mean difference is .414 in urban and .745 in metropolitan respectively. T- Value is 2.78 in urban area and rural with in metropolitan area is 3.87. Hence value is more than 2 so significant difference is visible as $\mathrm{p}$ value is

Table 3.1 Tukey Post-Hoc Test - I face problem in digital learning in lock down period as it is difficult to understand

\begin{tabular}{|c|c|c|c|c|c|}
\hline \multirow{2}{*}{$\begin{array}{l}\text { Residence } \\
\text { Rural }\end{array}$} & \multirow{2}{*}{$\begin{array}{l}\text { Statistics } \\
\text { Mean difference }\end{array}$} & Rural & Urban & \multicolumn{2}{|c|}{ Metropolitan } \\
\hline & & - & 0.365 & 0.4615 & * \\
\hline & $\mathrm{t}$-value & - & 2.46 & 2.400 & \\
\hline & $\mathrm{df}$ & - & 408 & 408 & \\
\hline & $\mathrm{p}$-value & - & 0.038 & 0.044 & \\
\hline \multirow[t]{4}{*}{ Urban } & Mean difference & & - & 0.0964 & \\
\hline & t-value & & - & 0.474 & \\
\hline & $\mathrm{df}$ & & - & 408 & \\
\hline & $\mathrm{p}$-value & & - & 0.884 & \\
\hline \multirow[t]{4}{*}{ Metropolitan } & Mean difference & & & - & \\
\hline & $\mathrm{t}$-value & & & - & \\
\hline & $\mathrm{df}$ & & & - & \\
\hline & $\mathrm{p}$-value & & & - & \\
\hline
\end{tabular}

Source: Authors' Calculations

Table 3.2 Tukey Post-Hoc Test - I do not have smartphone/laptop or device for digital learning

\begin{tabular}{|l|l|l|l|l|l|l|l|l|}
\hline Residence & \multicolumn{2}{|l|}{ Statistics } & Rural & Urban & \multicolumn{2}{l|}{ Metropolitan } \\
\hline Rural & Mean difference & & - & & 0.414 & & 0.745 & *** \\
\hline & t-value & & - & & 2.78 & 3.87 & \\
\hline & df & & - & & 408 & 408 & \\
\hline & p-value & & - & & 0.016 & $<.001$ & \\
\hline Urban & Mean difference & & & & - & & 0.331 & \\
\hline & t-value & & & & - & & 1.62 & \\
\hline & df & & & & - & & 408 & \\
\hline & p-value & & & - & & 0.237 & \\
\hline Metropolitan & Mean difference & & & & & - & \\
\hline & t-value & & & & - & \\
\hline & df & & & & - & \\
\hline & $\mathrm{p}$-value & & & & - & \\
\hline Note. ${ }^{*} \mathrm{p}<.05,{ }^{* *} \mathrm{p}<.01,{ }^{* * *} \mathrm{p}<.001$ & & & & \\
\hline
\end{tabular}


0.016 with rural and Urban as well as $p=0.001$ in rural vs. metropolitan. Decision rule says null hypothesis is rejected. But looking at observation of Urban Vs. Metropolitan area there is no significant difference in perception of students about impact of online learning about smartphone/laptop or device for digital learning as $\mathrm{p}$ value is 0.237 . Null hypothesis is accepted.

Table 3.3 indicates that there is significant difference in perception of students about do not have access to internet for digital learning with metropolitan area As Mean difference is .427 in urban and .653 in metropolitan respectively. T- Value is 2.78 in urban area and rural with in metropolitan area is 3.28 . Hence value is more than 2 so significant difference is visible as $p$ value is 0.016 with rural and Urban as well as $p=0.003$ in rural vs. metropolitan. Decision rule says null hypothesis is rejected. But looking at observation of Urban Vs. Metropolitan area there is no significant difference in perception of students about do not have access to internet for digital learning as $p$ value is 0.533 . Null hypothesis is accepted.

Table 3.4 indicates that there is no significant difference in perception of students about access to internet for digital learning with rural and urban area as Mean difference is .0430 in urban and .978 in metropolitan respectively. T- Value is .250 in urban area and. Hence value is less than 2 so no significant difference is visible as $p$ value is 0.966 with rural and Urban and decision rule says null hypothesis is accepted but rural with in metropolitan area is $t$ value is 4.40 as well as $\mathrm{p}=0.003$ in rural vs. metropolitan. Decision

Table 3.3 Tukey Post-Hoc Test - I do not have access to internet

\begin{tabular}{|c|c|c|c|c|c|}
\hline \multirow[b]{2}{*}{ Rural } & \multirow{2}{*}{ Mean difference } & Rural & Urban & \multicolumn{2}{|c|}{ Metropolitan } \\
\hline & & - & 0.427 & 0.653 & ** \\
\hline & t-value & - & 2.78 & 3.28 & \\
\hline & Df & - & 408 & 408 & \\
\hline & $p$-value & - & 0.016 & 0.003 & \\
\hline Urban & Mean difference & & - & 0.225 & \\
\hline & t-value & & - & 1.07 & \\
\hline & Df & & - & 408 & \\
\hline & $p$-value & & - & 0.533 & \\
\hline Metropolitan & Mean difference & & & - & \\
\hline & t-value & & & - & \\
\hline & Df & & & - & \\
\hline & $p$-value & & & - & \\
\hline
\end{tabular}

Source: Authors' Calculations

Table 3.4 Tukey Post-Hoc Test - I cant afford data package for digital learning

\begin{tabular}{|l|l|l|l|l|l|l|l|l|}
\hline Residence & \multicolumn{2}{l|}{ Statistics } & \multicolumn{2}{l|}{ Rural } & \multicolumn{2}{l|}{ Urban } & \multicolumn{2}{l|}{ Metropolitan } \\
\hline Rural & Mean difference & & - & & 0.0430 & & 0.978 & $* * *$ \\
\hline & t-value & & - & & 0.250 & 4.40 & \\
\hline & Df & & - & & 408 & 408 & \\
\hline & p-value & & - & & 0.966 & & $<.001$ & \\
\hline Urban & Mean difference & & & & - & & 0.935 & $* * *$ \\
\hline & t-value & & & & - & & 3.97 & \\
\hline & Df & & & & - & & 408 & \\
\hline & p-value & & & - & & $<.001$ & \\
\hline Metropolitan & Mean difference & & & & & - & \\
\hline & t-value & & & & - & \\
\hline & Df & & & & & - & \\
\hline & p-value & & & & & - & \\
\hline Note. ${ }^{*} \mathrm{p}<.05,{ }^{* *} \mathrm{p}<.01,{ }^{* * *} \mathrm{p}<.001$ & & & & \\
\hline
\end{tabular}

Source: Authors' Calculations 
rule says null hypothesis is rejected. But looking at observation of Urban Vs. Metropolitan area there is a significant difference in perception of students about do not have access to internet for digital learning as $p$ value is 0.001 . Null hypothesis is rejected.

Table 3.5 indicates that there is no significant difference in perception of students about lack of Electricity/regular power supply is problem in digital learning with rural and urban area As Mean difference is .310 in urban and .583 in metropolitan respectively. T- Value is 1.85 in urban area and. Hence value is less than 2 so no significant difference is visible as $p$ value is 0.153 with rural and Urban and decision rule says null hypothesis is accepted but rural with in metropolitan area is $t$ value is 2.70 as well as $p=0.020$ in rural vs. metropolitan. Decision rule says null hypothesis is rejected. But looking at observation of Urban Vs. Metropolitan area there is a significant difference in perception of students about lack of Electricity/regular power supply is problem in digital learning as $\mathrm{p}$ value is 0.458 . Null hypothesis is accepted.

Table 3.6 indicates that there is no significant difference in perception of students about problems in digital learning as it takes more time than traditional lecture with rural and urban area As Mean difference is .146 in urban and .496 in metropolitan respectively. T- Value is .958 in urban area and. Hence value is less than 2 so no significant difference is visible as $p$ value is 0.604 with rural and Urban and decision rule says null hypothesis is accepted but rural with in metropolitan area is $t$ value is

Table 3.5 Tukey Post-Hoc Test - lack of Electricity/regular power supply is problem in digital learning

\begin{tabular}{|c|c|c|c|c|c|}
\hline \multirow{2}{*}{$\begin{array}{l}\text { Residence } \\
\text { Rural }\end{array}$} & Statistics & Rural & Urban & \multicolumn{2}{|c|}{ Metropolitan } \\
\hline & Mean difference & - & 0.310 & 0.583 & s. \\
\hline & t-value & - & 1.85 & 2.70 & \\
\hline & Df & - & 408 & 408 & \\
\hline & $p$-value & - & 0.153 & 0.020 & \\
\hline \multirow[t]{4}{*}{ Urban } & Mean difference & & - & 0.273 & \\
\hline & t-value & & - & 1.19 & \\
\hline & Df & & - & 408 & \\
\hline & $p$-value & & - & 0.458 & \\
\hline \multirow[t]{4}{*}{ Metropolitan } & Mean difference & & & - & \\
\hline & $\mathrm{t}$-value & & & - & \\
\hline & Df & & & - & \\
\hline & $p$-value & & & - & \\
\hline
\end{tabular}

Source: Authors' Calculations

Table 3.6 Tukey Post-Hoc Test - I feel problems in digital learning as it takes more time than traditional lecture

\begin{tabular}{|c|c|c|c|c|c|}
\hline Residence & Statistics & $\mathbf{R u}$ & Urbar & Metr & \\
\hline \multirow{4}{*}{ Rural } & Mean difference & - & 0.146 & 0.496 & * \\
\hline & t-value & - & 0.958 & 2.51 & \\
\hline & Df & - & 408 & 408 & \\
\hline & $p$-value & - & 0.604 & 0.033 & \\
\hline \multirow[t]{4}{*}{ Urban } & Mean difference & & - & 0.350 & \\
\hline & t-value & & - & 1.67 & \\
\hline & Df & & - & 408 & \\
\hline & $\mathrm{p}$-value & & - & 0.217 & \\
\hline \multirow[t]{4}{*}{ Metropolitan } & Mean difference & & & - & \\
\hline & t-value & & & - & \\
\hline & Df & & & - & \\
\hline & $\mathrm{p}$-value & & & - & \\
\hline
\end{tabular}

Source: Authors' Calculations 
2.51 as well as $p=0.033$ in rural vs. metropolitan. Decision rule says null hypothesis is rejected. But looking at observation of Urban Vs. Metropolitan area there is a significant difference in perception of students about problems in digital learning as it takes more time than traditional lecture as $\mathrm{p}$ value is 0.217 . Null hypothesis is accepted.

Table 3.7 indicates that there is a significant difference in feel problems in digital learning as I do not have knowledge how to use as it takes more time than traditional lecture with rural and urban area As Mean difference is .146 in urban and .496 in metropolitan respectively. T- Value is 3.34 in urban area and. Hence value is less than 2 so significant difference is visible as $\mathrm{p}$ value is .003 with rural and Urban and decision rule says null hypothesis is accepted also rural with in metropolitan area is $t$ value is 6.27 as well as $\mathrm{p}<.001$ in rural vs. metropolitan. Decision rule says null hypothesis is rejected. Again looking at observation of Urban vs. Metropolitan area there is significant difference in perception of students about feel problems in digital learning as I do not have knowledge how to use as $p$ value is 0.002 . Null hypothesis is rejected major issue of digital learning mode but in case of understanding, rural students are more comfortable with traditional lectures as compared to urban and metropolitan students who are already in habit of getting digital lectures so earlier. Thus efforts are required to make the online content compatible to them. Similar results were found about the knowledge of how to use the smartphone or other digital media to access, retrieve and store the content. Hence it is also recommended that rural students should be made aware of how to use the digital media. Further, there is no significant association in the perception of students in rural, urban and metropolitan location about problem in digital learning in lock down period. Overall it can be concluded that more problems are being faced by rural area students in using digital media as a tool of learning as compared to the urban area and metropolitan area students. So, efforts should be made to enhance the efficacy of digital media as a tool of learning by providing practical exposure to the students about this media.

\section{Limitations of the study and future scope}

Data being collected via Google Form; the study could cover only those students who

Table 3.7 Tukey Post-Hoc Test - I feel problems in digital learning as I do not have knowledge how to use

\begin{tabular}{|c|c|c|c|c|c|}
\hline \multirow{2}{*}{$\begin{array}{l}\text { Residence } \\
\text { Rural }\end{array}$} & \multirow{2}{*}{$\begin{array}{l}\text { Statistics } \\
\text { Mean difference }\end{array}$} & Rural & Urban & \multicolumn{2}{|c|}{ Metropolitan } \\
\hline & & - & 0.502 & 1.221 & $* * *$ \\
\hline & $\mathrm{t}$-value & - & 3.34 & 6.27 & \\
\hline & Df & - & 408 & 408 & \\
\hline & $p$-value & - & 0.003 & $<.001$ & \\
\hline \multirow[t]{4}{*}{ Urban } & Mean difference & & - & 0.719 & $* *$ \\
\hline & $\mathrm{t}$-value & & - & 3.49 & \\
\hline & Df & & - & 408 & \\
\hline & $\mathrm{p}$-value & & - & 0.002 & \\
\hline \multirow[t]{4}{*}{ Metropolitan } & Mean difference & & & - & \\
\hline & $t$-value & & & - & \\
\hline & Df & & & - & \\
\hline & $p$-value & & & - & \\
\hline
\end{tabular}

\section{Source: Authors' Calculations}

\section{CONCLUSION}

Many students have been found friendly to use of digital media of learning. Further there is no significant difference in this regard among the different groups i.e. rural, urban and metropolitan. Almost same results were found regarding to availability of smart phone. Hence the smart phone is also not a were having smart phones and internet connectivity. This study examines the efficacy of digital learning as mode of learning in lock down period that will bring the attention of educational agencies, faculty members as well as policy makers towards the problems faced by the students in digital learning. Hence the findings of the study would be useful for the 
students, faculty members, educational institutions and government as well. As now India has entered in lockdown phase 4.0, so in future, researchers may study the perceptions of other stakeholders like faculty members, management, parents and government etc. to add the value in existing literature in this regard.

\section{REFERENCES}

Abdul Razzak, N.(2020). Paulo Freire"s critical and dialogic pedagogy and its implications for the Bahraini educational context. Educational Philosophy and Theory (Article in Press). Retrieved from: https://doi.org/10.1080/00131857.2020.17 16731

Abidah, A., Hidaayatullaah, H. N., Simamora, R. M., Fehabutar, D., \& Mutakinati, L. (2020). The Impact of Covid-19 to Indonesian Education and Its Relation to the Philosophy of "Merdeka Belajar". Studies in Philosophy of Science and Education, 1(1), 38-49. Retrieved from https://scie-journal.com/index.php/ SiPoSE/article/view/9

Chengyi L. (2020). Coronavirus and Business: The Insights You Need from Harvard Business Review. Retrieved from file:///C:/Users/user/Downloads/HBRcorona.pdf

Chinmi, Maichel, Marta, RF., Haryono, CG., Fernando, J., Goswami, JK. (2020). Exploring Online News As Comparative Study Between Vendatu at India and Ruan Guru from Indonesia in Covid 19. Journal of Content, Community \& Communication Amity School of Communication, 11(6), 167-176

Coronavirus: MINISTRY OF EDUCATION promotes digital platforms for students and teachers. Hindustan times. Retrieved from

https://www.hindustantimes.com/educa tion/coronavirus-outbreak-Ministry of Education-promotes-digital-platforms-forstudents-and-teachers/storyoNsHUsNV7mUZpVKNIxgXXL.html.

Kabha, R., Kamel, A., Elbahi, M., \& Narula, S. (2019). Comparison Study between the UAE, the UK, and India in Dealing with WhatsApp Fake News. Journal of Content,
Community and Communication, 10, 176186.https://doi.org/10.31620/JCCC.12. 19/18

Mahalakshmi, K. \& Radha R. (2020). COVID 19: A massive exposure towards web based learning. Journal of Xidian University. ISSN No.: 1001-2400. Volume 14, Issue 4, 2020, pg 2405-2411. https://doi.org/10.37896/jxu14.4/266

Michael Carrier, Ryan M. Damerow, Kathleen M. Bailey (2017). Digital Language Learning and Teaching: Research, Theory, and Practice. ISBN 9781138696815. Routledge, Oxfordshire, USA.

Nokelainen, P. (2006). An empirical assessment of pedagogical usability criteria for digital learning material with elementary school students. Interoperability of Educational Systems. Journal of Educational Technology \& Society (April, 2006). Vol. 9, No. 2, pp. 178197. Retrieved from https://www.jstor. org/stable/jeductechsoci.9.2.178

Sachdeva, P., \& Tripathi, D. (2019). A Critical Education for 21st Century: A Study on Youth and Media literacy. Journal of Content, Community and Communication, 10(9). https://doi.org/ 10.31620/jccc.12.19/07

Singh, P. (2019). New Media as a Change Agent of Indian Television and Cinema: A study of over the top Platforms. Journal of Content, Community and Communication, 9(2019), 131-137. https://doi.org/10.31620/JCCC.06.19/18

The Jamovi Project (2019). Jamovi. (Version 1.0) [Computer Software]. Retrieved from https://www.jamovi.org.

Warschauer, M. (2007). The Paradoxical Future of Digital Learning. Learn Inq 1, 41-49. Retrieved from https://doi.org/ 10.1007/s11519-007-0001-5

Zakharova Nadezhda, Polyakov Kirill et.al. (2019). Developing key competencies in the digital economy for students in higher education. SPBPU IDE '19: Proceedings of the 2019 International SPBPU Scientific Conference on Innovations in Digital Economy. October 2019 Article No.: 2 Pages 1-6. Retrieved from: https://doi. org/10.1145/3372177.3372208 